JIIP: Jurnal Ilmiah IImu Pemerintahan

Volume 5, Nomor 2, Tahun 2020

DOI: $10.14710 / j i i p . v 5 i 2.8593$

\title{
Desentralisasi dan Resentralisasi: Upaya Menyeimbangkan Pendulum Pusat-Daerah
}

\author{
Priyatno Harsasto \\ Prodi Ilmu Pemerintahan, Universitas Diponegoro
}

Dikirimkan: 2 Agustus 2020

Direvisi: 17 September 2020

Diterbitkan: 30 September 2020

\section{INTISARI}

Kebijakan desentralisasi di Indonesia belum juga mampu memenuhi harapan akan munculnya pemerintahan demokratis yang membawa kesejahteraan pada masyarakat. Penelitian ini bermaksud untuk mengulik masalah yang muncul dalam proses pemaknaan desentralisasi politik saat ini. Dengan menggunakan pendekatan studi kasus yang mengandalkan data-data sekunder, penelitian ini mencermati dinamika politik desentralisasi di Jawa Tengah. Desentralisasi memang telah berhasil meningkatkan kapasistas birokrasi dalam menyediakan pelayanan publik, namun pengembangan karir birokrat seringkali tergantung pada hubungan personal daripada institusional. Di samping itu, upaya peningkatan efisiensi pelayanan publik pada saat yang sama dikuatkan dengan upaya resentralisasi birokrasi yang membatasi otonomi birokrasi.

\section{KATA KUNCI}

birokrasi; desentralisasi; resentralisasi; otonomi; efisiensi

\section{Pendahuluan}

ejak tahun 1980 an sejumlah negara berkembang mulai mendesentralisasikan
fungsi-fungsi pemerintahan kepada pemerintah daerah. Desentralisasi
merupakan pendistribusian pertanggungjawaban keuangan, politik dan administrasi dari pemerintah nasional kepada pemerintah di bawahnya (Litvack, Ahmad, \& Bird, 1998: 4). Kebijakan desentralisasi terjadi di semua belahan bumi dengan alasan yang berbeda-beda dan dengan konteks sosial, politik dan ekonomi yang beragam. Pembuat kebijakan, praktisi pembangunan dan akademisi memandang desentralisasi sebaga alat untuk memperbaiki pelayanan publik, mempercepat pertumbuhan ekonomi, mengurangi

\section{Korespodensi:}

Prodi Ilmu Pemerintahan, Fakultas Ilmu Sosial dan Ilmu Politik, Universitas Diponegoro, Jalan Professor Soedarto SH, Tembalang, Kec. Tembalang, Kota Semarang, Jawa Tengah 50139.

Email: priyatnoharsasto@lecturer.undip.ac.id 
korupsi, memperkuat demokrasi, dan memperkuat dukungan publik terhadap pemerintah sehingga memperkuat legitimasi pemerintah. Sejak tahun 1990 an pandangan ini mendapatkan dukungan secara global diantara negara dan lembaga-lembaga donor internasional seperti yang dikatakan Blair (2000) bahwa pelaksanaan pemerintahan lokal yang demokratis dengan menjalankan program devolusi mendorong partisipasi dan akuntabilatas yang tinggi, pada gilirannya akan dapat membuat domokratisasi berjalan dengan baik. Pemikiran desentralisasi demokrasi inilah yang mendorong upaya agar pemerintah lebih bertanggungjawab, transparan, dan responsif, karenanya harus dimulai dari level pemerintah sub-nasional. Nilai-nilai yang diusung terutama partisipasi yang lebih luas untuk memperbaiki model sentralisasi yang telah mengakar. Partisipasi masyarakat mendorong inklusif preferensi masyarakat dalam pembuatan kebijakan, sehingga meningkatkan akuntabilitas, transparansi dan responsifitas pemerintah, nasional maupun sub-nasional.

Di Indonesia, proses demokratisasi atas sistem politik yang sangat terpusat ditandai dengan runtuhnya rejim Orde Baru di bawah presiden Suharto di tahun 1998. Keruntuhan Orde Baru mengantarkan kepada Era Reformasi, dan mendorong terjadinya perubahan rejim setelah 32 tahun dominasi negara atas masyarakat. Seperti yang terjadi di banyak negara lain, desentralisasi mengandung di dalamnya proses demokratisasi. Tokoh utama otonomi daerah di Indonesia Rasyid (2007: 23), mengatakan "Demokrasi muncul bersamaan dengan desentralisasi. Dengan kata lain tidak akan ada demokrasi tanpa desentralisasi." Dengan demikian diharapkan apabila demokrasi dikombinasikan dengan desentralisasi maka warisan rejim otoriter seperti kekerasan negara, pembangunan yang tidak merata dan kebebasan yang terbelenggu, serta kekuatan sentrifugal, konflik etnis dan agama serta konflik komunal akan perlahan menghilang. Pandangan optimistis semacam ini menjadi tema yang disetujui pengamat Indonesia pada umumnya. William Liddle, pengamat Indonesia terkemuka, berpendapat bahwa keberhasilan proyek demokratisasi Indonesia paska Suharto akan sangat tergantung pada desentralisasi dalam proses demokratisasi politik lokal dan dalam membangun fondasi dari demokratisasi administrasi, politik, ekonomi, sosial dan budaya pada level nasional (Aspinall, 2003; Fealy, 2013).

Sejumlah penelitian tentang desentralisasi di Indonesia mengidentifikasikan berbagai masalah demokratisasi dan implikasinya. Tema utama dari penelitian-penelitian sebelumnya adalah desain kelembagaan desentralisasi pemerintah daerah, kapasitas organanisasi pemerintah daerah dalam menyediakan pelayanan publik, dan dampak UU Pemerintah Daerah dan paraturan administrasi, bisnis dan keuangan lokal. Masalah utama dari penelitian-penelitian yang ada terutama adalah masalah dan implikasi kebijakan desentralisasi hanya dianalisis melalui kacamata pemerintah pusat. Bank Dunia (2003) 
mengidentifikasikan 4 masalah desain desentralisasi di Indonesia. Pertama, pemberian fungsi-fungsi dari tingkat-tingkatan pemerintahan sub-nasional tidak jelas; kedua, masalah kapasitas pemerintahan tingkat bawah dalam menjalankan fungsinya;ketiga, sistem keuangan antar pemerintahan daerah yang tidak seimbang; keempat, akuntabilitas rendah dari pemerintahan lokal terendah. Kajian dari Asia Foundation $(2002,2004)$ melaporkan dengan mengkaji data dari 30 kabupaten bagaimana pemerintah daerah mampu mengelola tanggungjawab yang diserahkan kepada mereka. Kajian dengan persepektif yang berbeda dilakukan Harsasto (2015) yang memberikan fokus kepada kapasistas kepemimpinan dalam mengatasi persoalan desain kelembagaan desentralisasi.

Meskipun penelitian-penelitian yang direview sebelumnya memberikan suatu roadmap tentang bagaimana desentralisasi dan demokrasi dijalankan di Indonesia paska reformasi, analisis terlalu menekankan aspek teknis kelembagaan di satu sisi, atau menekankan aspek politik kepemimpinan di sisi yang lain. Penelitian-penelitian tersebut kurang memberikan tempat bagi politik implementasi kelembagaan desentralisasi. Dengan memperhatikan dua jenis penelitian yang dikaji di atas, penelitian yang memperhatikan kondisi desain kelembagaan dan konsekuensi politik implementasinya perlu mendapatkan perhatian.

Evaluasi pelaksanaan desentralisasi tidak hanya melihat adanya penerapan yang menyimpang atau sesuai dengan desain kelembagaan desentralisasi, namun harus memperhatikan bagiamana konteks politik proses pemerintahan memiliki pengaruh yang signifikan terhadap politik implementasi desentralisasi. Oleh karena itu perlu dikaji perspektif pemerintah sub-nasional dalam melakukan analisis dinamika reformasi pemerintahan lokal saat ini. UU Otonomi Daerah era reformasi telah mengalami beberapa perubahan. UU No 22 Tahun 1999 yang masih memberikan kewenangan besar kepada DPRD untuk memilih kepemimpinan daerah, diubah menjadi UU No. 32/2004 tentang Pemerintahan Daerah yang memungkinkan pemilihan kepala daerah secara langsung. UU ini dianggap masih belum cukup memberikan ruang bagi interaksi yang lebih dinamis diantara pemerintah sub-nasional, terutama diantara pemerintah provinsi dan pemerintah lokal. UU No.23/2014 mengisi kekurangan tersebut. UU No.123/2014 ditindaklanjuti dengan Peraturan Pemerintah No.18/2016 tentang perangkat daerah. Di Jawa Tengah PP ini ditintaklanjuti dengan Perda No.9/2016 tentang Penataan Organisasi Perangkat Daerah Pemerintah Provinsi Jawa Tengah.

Tahun 1990-an gelombang reformasi desentralisasi melanda dunia karena dorongan faktor ekonomi dan politik. Krisis ekonomi yang terjadi telah menyebabkan krisis legitimasi elit pemerintahan. Berkurangnya anggaran pemerintah lebih jauh lagi telah mengikis struktur klientelistik yang dimanfaatkan para politisi untuk mengikat konstituen mereka. Pada saat yang sama gerakan demokrasi yang signifikan berkembang pesat. Gerakan ini 
membawa tuntutan baru dan memberikan kekuatan tantangan terhadap struktur politik yang ada. Dalam konteks ini elit negara memanfaatkan desentralisasi sebagai alat untuk mengalihkan ketidakpuasan masyarakat dari arena nasional ke daerah untuk mendorong kepercayaan masyarakar kepada sistem politik. Upaya ini diharapkan dapat mencegah perubahan politik yang tidak diharapkan, namun hal ini telah menghasilkan kehebohan politik berkepanjangan. Oleh karena itu, perspektif state-centric ini digeser kepada perspektif society-centric, dimana policy making dan governing process bertumpu pada masyarakat. State yang direpresentasikan oleh pemerintah hanya berfungsi sebagai fasilitator dan penyedia layanan, dan inklusi adalah mekanisme untuk meletakkan tumpuan governing process itu pada masyarakat. Partisipasi, dengan demikian menjadi basis bagi bekerjanya governance menggantikan perspektif pembangunan yang terpusat pada negara (Ito, 2006: 138). Dalam konteks transformasi politik negara-negara berkembang, inklusi warga negara ini menguat seiring dengan tumbangnya rezim otoritarian, yang merupakan penanda paradigma state-centric, mengisi proses reformasi politik dan demokratisasi.

Dengan mempertimbangkan berbagai tanggapan dan hasil pelaksanaan desentralisasi di Indonesia, penting kiranya untuk meneliti proses reformasi pemerintahan, yakni bagaimana dan mengapa inisiatif penataan kelembagaan sebagai bagian dari reformasi pemerintahan muncul dalam bayang-bayang kepentingan pemerintah pusat? Untuk memenuhi tujuan tersebut, penelitian ini merupaan penelitian kualitatif yang menggunakan pendekatan studi kasus yang mengandalkan telaah pustaka. Menurut Yin (2003: 4) studi kasus dapat digunakan untuk menjelaskan dan menggambarkan atau melakuka eksplorasi suatu peristiwa atau fenomena dalam konteks keseharian terjadinya fenomena tersebut. Oleh karena itu akan sangat membantu memahami dan menjelaskan hubungan dan arah dari suatu inisiatif kebijakan. Dengan menggunakan pendapat yang dikemukakan oleh Stake (1995) penelitian ini dapat dikategorikan sebagai studi kasus instrumental, yaitu studi kasus yang digunankan untuk mendapatkan pemahaman yang lebih baik mengenai isu atau fenomena tertentu. Analisis dilakukan dengan mencermati perundang-undangan tentang Pemerintah Daerah dan secara empirik dari perspektif provinsi Jawa Tengah. Penelitian ini memotret reaksi pemerintah provinsi dalam menyikapi perubahan kelembagaan dalam kerangka desentralisasi

\section{Penguatan Governance di Daerah: Kembali Ke Sistem Prefektoral}

Desentralisasi menggeser hampir sebagian besar urusan yang sebelumnya secara dominan ditangani oleh pemerintah pusat kepada pemerintah daerah. Urusan paling 
banyak yang didesentralisasikan adalah urusan pelayanan publik. Harus disadari bahwa diferensiasi teritorial dan fungsional telah menghasilkan sistem pengambilan keputusan dimana masalah-masalah publik dikelola dan diselesaikan di tingkat lokal; bagian-bagian yang terpisah berurusan dengan tugas-tugas terbatas dan mengendalikan informasi, sumberdaya dan kepentingan yang berbeda-beda. Namun, pemerintah terus menerus dihadapkan pada tugas-tugas dimana masalah-masalah dan solusinya cenderung melewati batas-batas yurisdiksi kewilayahan dan kewenangan yang terpisah. Interdependensi masalah cenderung meningkat seiring dengan makin kompleksnya kebutuhan kelembagaan penyedia barang-barang publik. Kebutuhan akan lembaga yang menjamin kohesi dan standardisasi serta koordinasi menjadi krusial. Desentralisasi dalam bentuk devolusi kekuasaan yang ada saat ini menjadi tantangan kelembagaan untuk mensinergikan kekuatan tiap-tiap level pemerintahan, dari pusat, regional sampai tingkatan lokal. Ini merupakan langkah krusial dalam rangka mengefektifkan fungsi desentralisasi sebagai bagian dari upaya penguatan governance di daerah. Jika tidak, sebagaimana The World Bank (2009), maka berbagai penyediaan layanan publik akan mengalami hambatan yang signifikan, sehingga jurang kesejahteraan akan semakin tajam, bahkan stabilitas makroekonomi dapat terancam. The World Bank menunjuk contoh yang terjadi di Filipina dan Kolombia untuk memperlihatkan bagaimana kegagalan desentralisasi menyebabkan dalam penyediaan layanan publik yang buruk. Bahkan masalah makroekonomi di beberapa negara Amerika Latin sebagian besar juga dapat dirunut pada gagalnya proses desentralisasi.

Pada dasarnya sistem prefektoral dipahami sebagai sistem yang menekankan dan melayani kebutuhan sentralisasi pada negara-negara Napoleonistik di Eropa Barat dan Selatan. Seorang prefek adalah pejabat pusat yang ditempatkan di daerah. Prefek dibutuhkan untuk melakukan supervisi dan mengontrol tindakan pemerintah daerah serta menjamin tugas-tugas pemerintahan telah dijalankan sesuai aturan hukum yang ada (Ashford, 1993: 28). Prefek menjamin standardisasi dalam kinerja administrasi secara keseluruhan dalam negara kesatuan. Karakteristik seperti ini menciptakan pandangan bahwa prefek melayani kepentigan pemerintah pusat, dan sistem prefektoral dipahami sebagai pola kelembagaan yang membatasi otonomi lokal.

Dalam situasi ketika pemerintah lokal tidak cukup dapat dikendalikan oleh pemerintah pusat, dengan demikian sistem prefektoral menjadi pilihan yang menarik untuk diterapkan, dan Indonesia telah menerapkan sistem ini pada UU No.5/1974. Desain sistem prefektoral dapat digunakan untuk mengukur tingkat desentralisasi pada regim pemerintahan yang berbeda (Smith, 1976: 217). Pendapat ini didasarkan dua argumen dasar. Pertama, seorang prefek memiliki dan menggunakan kekuasaannya untuk mengurangi diskresi lokal dalam persoalan penting yang dilaksanakan pemerintah daerah. 
Kedua, seorang prefek menjadi perwakilan pemerintah pusat pada tingkat lokal. Peran prefektoral dapat berupa berbagai bentuk dan pertanyaan mendasar yang perlu dikemukakan adalah apakah semua bentuk yang ada berimplikasi pada pembatasan pengaruh lokal dan sistem sentralisasi. Prefek bisa atau tidak bisa memiliki tanggungjawab koordinasi yang komprehensif atau kekuasaan untuk menjalankan keputusan pada isu-isu lokal. Lebih jauh lagi, kekuasaan tersebut bisa atau tidak bisa digunakan untuk mempromosikan suatu unifikasi rasional atas kepentingan lokal dan nasional. Prefek, dengan demikian, memiliki tanggungjawab yang mendalam terhadap pemerintahan daerah.

Kewenangan prefek bervariasi dengan tugas-tugas yang mereka laksanakan dan tanggungjawab yang mereka miliki dan bisa jadi sangat kuat atau sewajarnya saja. Seorang prefek yang hanya memperbaiki aturan dari pelaksanaan sejumlah tugas jelas kurang kuat kekuasaannya dibandingkan seorang prefek yang menjalankan kekuasaannya atas isu-isu strategis yang menjadi kepentingan vital masyarakat lokal. Model kekuasaan prefek yang kedua dapat dilihat sebagai penghalang serius bagi otonomi lokal atau bisa juga kekuasaan yang dimiliki digunakan untuk menyeimbangkan kepentingan pusat dan kepentingan lokal.

Negara memiliki fungsi penting dan sah dalam menggunakan kekuasaan kontrol terhadap pemerintahan lokal. Tugas dari pemerintah pusat adalah menjamin perlindungan hukum, stabilitas ekonomi makro, menjamin keamanan dari ancaman luar maupun domestik, dan menjaga lingkungan lokal demi kepentingan generasi masa depan. Pemerintah pusat harus menjamin keadilan dan standardisasi pada masyarakat dan wilayah serta menyediakan kesejahteraan seperti pelayanan kesehatan dan pendidikan untuk seluruh negeri. Desentrlalisasi dikatakan menghasilkan kompetisi diantara unit-unit lokal ketika mereka berjuang untuk menciptakan kondisi yang lebih baik secara komparatif agar mampu menarik investor dan pembayar pajak yang kaya dari luar wilayah mereka (Goldsmith, 1995: 239). Pemerintah pusat harus memiliki legitimasi untuk melakukan intervensi, untuk itulah pemerintah pusat dilengkapi kekuasaan untuk menghandel masalah-masalah inheren yang rumit dan menjalankan agenda koordinasi yang efisien. Ini membutuhkan struktur kontrol yang kuat untuk menjamin kelancaran tindakan pemerintah lokal. Disamping itu, delegasi kewenangan ektensif kepada unit-unit yang lebih kecil membuat sulit pembuat kebijakan untuk menangani masalah-masalah mereka sendiri yang makin rumit (Segal, 1997). Inilah sebabnya menurut Scharpf (1978: 352) dibutuhkan coordinating interaction diantara pemerintah lokal dan pusat pada masyarakat modern. Ada kebutuhan bagi suatu bangsa untuk berfungsi sebagai entitas kohesif, dan keburuhan untuk menjamin unit lokal tidak saling bertentangan dalam mengelola pemerintah lokal. 
Desentralisasi dengan demikian dapat dianggap sebagai tatanan yang kurang birokratis namun lebih politis. Pemerintah lokal bertindak untuk menyediakan alokasi barang-barang publik dan jasa secara efisien, sedangkan sentralisasi dianggap menyebabkan terlalu banyaknya aturan. Keputusan yang dilakukan pada level pusat dianggap kurang fleksibel, kurang inovativ dan berdasarkan pengetahuan yang kurang komprehensif dibandingkan yang dimiliki pemerintah lokal (De Vries, 2000). Kekuasaan desentralisasi dari pemerintah pusat kepada unit-unit lokal merujuk pada nilai-nilai demokrasi seperti partisipasi, kesamaan dan efisiensi, dan kebutuhan suatu pembagian kekuasaan dipahami penting dalam pelaksanaan demokrasi. Singkat kata, terdapat interdependensi diantara pemerntah pusat dan daerah dalam menjamin adanya legitimasi sistem politik. Inilah yang menyebabkan diperlukannya suatu lembaga untuk menyeimbangkan kepentingan nasional dan lokal.

Tidak ada kesepakatan tentang kekuasaan dan kemampuan apa yang seharusnya dimiliki pemerintah pusat dan lokal pada negara modern, dan dalam praktek kenegaraan terdapat pergeseran terus menerus diantara sentralisasi, desentralisasi dan resentralisasi, berupa pergeseran kewenangan atas kebijakan yang didomnasi pemerintah pusat bergerak ke arah pemerintah lokal dan kembali lagi ke pusat (De Vries, 2000: 194). Dalam situasi seperti ini sistem prefektoral dipandang sebagai token sentralisasi dan akan melemah ketika desentralisasi menjadi topik politis.

Desain tradisional dan hirarkis belum tentu merupakan cara terbaik dalam mengatasi masalah penyediaan barang-barang publik. Konteks baru dengan ciri masalahmasalah lintas wilayah ini mengindikasikan bahwa hirarki tradisional dalam proses governance sulit dijalankan dan tidak mencukupi. Desain hirarkis tidak akan efektif jika masalah dan solusi melampaui lintas wilayah kewenangan dan yurisdiksinya karena ektensifikasi sistem pemerintahan dan sifat interdependen dari masalah. Asal dan cakupan dari suatu masalah tertentu tidak selalu masuk dalam satu unit wilayah politik. Bisa terjadi suatu masalah dalam, misalnya pembangunan regional, muncul dari aturan yang dibuat pemerintah pusat. Oleh karenanya masalah ini tidak dapat diselesaikan oleh mereka yang terkena dampaknya (pemerintah kota dan komunitas lokal). Masalah bisa juga muncul dari bawah ketika praktek pemerintahan lokal melemahkan prioritas pusat. Bisa juga ditemukan pemerintah kota yang terlibat persaingan destruktif yang menyebabkan munculnya situasi seperti 'the tragedy of the commons'. Unit-unit ini interdependen sehingga dibutuhkan lembaga yang mendorong kerjasama dan sharing informasi diantara unit-unit politik yang ada. Pada saat yang sama muncul juga kebutuhan adanya lembaga top-down untuk menjalankan koordinasi dan kohesi dalam sistem politik. Sistem prefektoral dipandang merupakan lembaga yang menjalankan kekuasaan hirarkis atas nama pemerintah pusat dan mampu menyediakan penghubung pertukaran informasi 
diantara pemerintah pusat dan pemerintah lokal. Jadi pada akhirnya sistem prefektoral menjadi penghubung untuk menyediakan pertukaran infomasi, koordinasi dan kohesi diseluruh wilayah negara. Suatu penghubung yang mampu menyeimbangkan kepentingan pusat dan daerah.

Dengan diberlakukannya UU No.23/2014 hubungan pemerintah lokal dan pemerintah atasan kembali bersifat hirarkis. Pasal-pasal 2 sampai dengan 4 UU No.23/2014 menekankan hubungan hirarkis pusat-daerah.Sedangkan pasal-pasal 5-8 menekankan kekuasaan pemerintah yang dipersonifikasikan pada figur presiden sebagai sumber semua kewenangan yang didelegasikan ke daerah. UU ini membawa sistem pemerintahan daerah Indonesia kembali kepada sistem prefektoral yang lama ditinggalkan dengan digantikannya UU No 5/1974..UU No.23/2014 menjamin kohesi dan koordinasi hubungan pusat-daerah, dan hubungan pemerintah provinsi dan pemerintah lokal. Sistem prefektoral diakui sebagai sistem yang menjadi dasar sentralisasi. Seorang prefek yang diwujudkan dalam jabatan gubernur, merupakan wakil pusat di daerah. Seorang prefek dibutuhkan untuk melakukan supervisi dan mengawasi tindakan pemerintah lokal sehingga tugas-tugas dan urusan-urusan pemerintahan dijamin mengikuti aturan yang berlaku (Smith, 1976). UU ini sangat jelas memperkuat posisi gubernur sebagai perwakilan pemerintah pusat. Gubernur memiliki kewenangan untuk menjamin standardisasi kinerja administrasi seluruh daerah di Indonesia. Karakteristik seperti ini mencerminkan peran prefek sebagai alat pemerintah pusat dan kekuatan kontrol pusat. Dengan diberlakukannnya sistem prefektoral sebagai model desentralisasi saat ini, di satu sisi kekuasaan diskresi daerah menjadi lebih terbatas, namun di sisi yang lain efisiensi pelaksanaan pemerintahan menjadi lebih terjamin.

\section{Mengulik Desentralisasi di Jawa Tengah Sebagai Contoh Kasus}

Pelaksanaan desentralisasi harus memertimbangkan dua hal, yaitu kekenyalan struktur organisasi dan kualitas sumberdaya manusianya. Meskipun struktur birokrasi telah dibuat sebaik-baiknya, tidak akan memberikan hasil yang optimal jika para birokrat tidak menjalankan tugas seperti yang seharusnya. Bentuk-bentuk penyalahgunaan wewenang dan kekuasaan membuat UU Nomor 5 Tahun 2014 tentang Aparatur Sipil Negara menemui jalan terjal dalam pelaksanaannya. Resistensi dan praktik penyimpangan terjadi. Selama ini birokrat begitu lama menikmati kehidupan yang nyaman, tiba-tiba harus membuktikan kualitas kerja mereka setiap saat secara kompetitif dalam promosi yang menggunakan sistem merit dan terbuka melalui lelang jabatan. Bagi politisi UU ini juga menjadi penghalang yang nyata, karena mereka akan sangat kesulitan dalam memanfaatkan pengaruh mereka dalam mendikte rotasi pegawai karena sistem pengawasan yang berlapis. Rumitnya permasalahan di atas dapat ditilik dari munculnya 
keinginan dari politisi untuk membubarkan Komisi Aparatur Sipil Negara (KASN). Nampak sekali kegamangan poltisi dalam menyikapi perubahan system pengawasan yang melibatkan pihak non struktural dalam menjaga sistem metir dan netralitas ASN. Meskipun demikian praktik jual-beli jabatan masih juga terjadi dan diduga melibatkan uang yang sangat besar senilai Rp 35 triliun sulit. Keterlibatan ASN dalam kontestasi politik juga masih menjadi masalah. Boleh dikatakan setiap petahana akan berusaha memobilisasi ASN dengan segala cara termasuk ancaman-ancaman yang berkaitan dengan promosi dan penempatan.

Permasalahan desentralisasi terkait dengan masalah penyalahgunaan wewenang yang memiliki efek domino. Promosi yang didasarkan pada spoil system akan mendorong korupsi dari para pejabat yang mendapatkan jabatannya dari proses komersialisasi tadi. Sering kita mendengar adanya tekanan dari pejabat yang memiliki posisi strategis pada anak buah mereka untuk melakukan gratifikasi dalam rangka kenaikan jabatan, pemanfaatan jabatan dalam proses perijinan, pengadaan barang/jasa, anggaran, yang seja awal telah diposisikan sebagai area pemburuan rente. Politisasi birokrasi akan berimplikasi terhadap kualitas pelayanan dan efisiensi birokrasi. Para birokrat yang mendapatkan jabatan melalui sistem spoil, tidak memiliki integritas dan kemampuan yang mencukupi untuk membangun budaya birokrasi yang baik. Hubungan-hubungan patron-kilen serta replikasi budaya feodal lebih diutamakan daripada peningkatan kompetensi dan integritas birokrasi. Pada gilirannya masyarakat yang akan merasakan akibatnya karena korupsi anggaran serta birokrasi yang tidak efisien akan mempengaruhi kualitas pelayanan publik yang disediakan.

Pelayanan publik di Jateng juga telah menunjukkan adanya peningkatan pelayanan yang baik. Pada tahun 2016 ini provinsi Jawa Tengah mendapatkan penilaian terbaik dalam reformasi birokrasi oleh Kementrian Pendayagunaan Aparatur Negara dan Reformasi Birokrasi (Kemenpan RB). Penilaian dilakukan dengan mengukur delapan area perubahan reformasi birokrasi, yakni mental aparatur, pengawasan, akuntabilitas, kelembagaan, tatalaksana, SDM aparatur, peraturan perundang-undangan, dan pelayanan public (TribunJateng.com, 2017). Selain itu, evaluasi juga dilakukan terhadap indeks reformasi birokrasi dan tanggapan masyarakat melalui penilaian lapangan. Beberapa program provinsi Jateng yang dinilai berhasil di antaranya lelang jabatan dari eselon I hingga IV, pelaporan LHKPN hingga pejabat eselon IV, pelaporan gratifikasi seluruh pejabat, peningkatan tunjangan pegawai dan pelayanan publik mudah murah cepat (GoRiau.com, 2017). Di samping itu tiga inovasi pelayanan publik yang dibuat Pemerintah Provinsi Jawa Tengah, masuk dalam top 99 inovasi pelayanan publik dari Kementerian PAN dan Reformasi Birokrasi (Jatengprov.go.id, 2017). Ketiga inovasi itu antara lain penyederhanaan prosedur pendaftaran rumah sakit melalui Si Bina Cantik (sistem bridging 
sim RSMS, BPJS, dan INA CBG'S menuju akuntabilitas, transparansi, dan efisiensi pelayanan kesehatan JKN secara paripurna), dan penetrasi online (pengembangan sistem SMS gateway menuju registrasi online) oleh RSUD Prof $\mathrm{Dr}$ Margono Soekarjo, Serta Layanan Peluk My Darling (perawatan luka kusta secara menyeluruh dengan menggunakan healing garden ${ }^{1}$ )yang diciptakan RSUD Kelet Jepara. Namun, budaya feodal dalam birokrasi perlu dikikis sehingga paradigma pelayanan yang menekankan masih bertumpu pada keinginan untuk "dilayani" berubah menjadi "pemberian pelayanan yang optimal". Oleh karena itu dalam menyusun mekanisme kerja perlu diperhatikan integrasi kemampuan SDM, penguatan teknologi, dan budaya birokrasi yang baik. Apabila hal ini bisa dijalankan dengan baik maka upaya yang telah dilakukan untuk melakukan untuk memangkas waktu proses perijinan menjadi lebih singkat, akan meningkatkan daya saing global kalau dapat diimbangi dengan pemberantasan korupsi, meningkatkan efisiensi kerja birokrasi dan peningkatan infrastruktur secara signifikan.

Dalam kasus penataan Penataan Organisasi Perangkat Daerah (OPD), terlihat upaya daerah untuk meminimalkan perubahan seperti yang dikendaki UU. Penataan OPD dilaksanakan berdasarkan PP No. 18 Tahun 2016 tentang Perangkat Daerah. PP No. 18/ 2016 ini merupakan tindak lanjut dari Pasal 232 ayat (1) UU No. 23 Tahun 2014 tentang Pemerintahan Daerah. Dalam UU No. 23 Tahun 2014 dijelaskan pembagian urusan antara pemerintah pusat, pemerintah provinsi dan pemerintah kabupaten/ kota. Urusan ini dibagi menjadi tiga yaitu urusan pemerintahan absolut, urusan pemerintahan konkuren dan urusan pemerintahan umum. Urusan pemerintahan konkuren inilah yang dibagi antara pemerintah pusat dan daerah yang terdiri dari urusan wajib (berkaitan dengan pelayanan dasar dan non-pelayanan dasar) dan urusan pilihan (hanya dapat diselenggarakan oleh daerah yang memiliki potensi unggulan dan kekhasan daerah) yang kemudian menjadi dasar dari adanya penataan OPD.

Tidak ada perubahan signifikan yang membedakan OPD Kota Semarang saat berpedoman dengan PP No. 18 Tahun 2016 dengan PP sebelumnya, yaitu PP No. 41 Tahun 2007. Salah satu tujuan penataan OPD ini adalah untuk meningkatkan pelayanan publik, sehingga nilai efisiensi harus dipikirkan secara matang, namun dalam UU No. 23 Tahun 2014 yang menjadi landasan lahirnya PP No. 18 Tahun 2016 sendiri tidak mengharuskan pemerintahan daerah untuk melakukan perampingan struktur guna mencapai efisiensi tersebut. Sehingga dalam proses penataan ini, Kota Semarang menggunakan prinsip tepat ukuran (Right Sizing) dan menjadi tidak memfokuskan pencapaian efisiensi, karena dari hasil penelitian menunjukkan bahawa jumlah SKPD Kota Semarang tidak mengalami perampingan. Jumlahnya tetap dan tergolong gemuk, yaitu sebanyak 52 SKPD. Adanya penggabungan dinas, seperti Dinas Pasar bergabung dengan Dinas Perdagangan, Dinas Kelautan bergabung dengan Dinas Perikanan diikut dengan pemecahan dinas, seperti 
Bapermasper-KB dipecah menjadi Dinas Pemberdayaan Perempuan dan Perlindungan Anak dan Dinas Pengendalian Penduduk dan KB. Jadi dapat disimpulkan penataan OPD di Kota Semarang hanya seperti tambal sulam saja, struktrunya berubah namun jumlahnya tetap.

Penataan OPD berdasarkan UU No. 23 Tahun 2014 membagi jenis-jenis urusan kedalam 32 urusan secara rinci. Nama dinas dan badan di Pemkot Semarang menunjukan jenis urusan yang menjadi kewenangan mereka, hal ini bertujuan agar tidak terjadi tumpang tindih tugas dan fungsi. Selain pembagian urusan antar dinas dan badan, dalam UU No. 23 Tahun 2014 juga dibagi jelas kewenangan antara pemerintah pusat, pemerintah provinsi dan pemerintah kabupaten/ kota. Pembagian kewenangan ini mengakibatkan beberapa kewenangan Pemkot Semarang diambil alih oleh Pemprov Jawa Tengah, yang tentunya akan mengurangi beban kerja Pemkot Semarang. Kewenangan tersebut adalah kewenangan terkait pendidikan menengah, kewenangan batas laut sepanjang 0-4 mil dari garis pantai, kewenangan ESDM dan kehutanan.

Dapat dilihat, bahwa UU No. 23 Tahun 2014 hendak menampilkan skema hubungan yang lebih tertata antara pemerintah pusat, pemerintah provinsi dan pemerintah kabupaten/ kota sehingga tercipta porsi yang proporsional antar level pemerintahan serta tercipta keharmonisan dalam pelaksanaan pembangunan dan pelayanan publik. UU No. 23 Tahun 2014 yang diterjemahkan dalam PP No. 18 Tahun 2016 ini menganut sistem perfektoral dimana pasal-pasal yang mendasari penataan OPD menunjukkan bagaimana mengkaitkan kembali hubungan pemerintah kota dan pemerintah provinsi sehingga hubungan yang tebentuk menjadi hirarkis.

Kini pemerintah provinsi memiliki kewenangan untuk pengawasi dan membina terhadap jalanya pemerintahan kabupaten/ kota tanpa mengurangi nilai dari otonomi daerah. Untuk mempermudah koordinasi antara pemerintah kota dan pemerintah provinsi, maka sesuai amanah PP No. 18 Tahun 2016 dibentuklah Permendagri No. 12 Tahun 2017 tentang Pedoman Pembentukan dan Klasifikasi Cabang Dinas dan UPTD. Pembentukan cabang dinas ini berkaitan dengan adanya beberapa kewenangan yang diambil alih oleh pemerintah provinsi, tujuanya adalah untuk mempersingkat dan mempermudah koordinasi. Namun dalam penerapannya, lembaga-lembaga yang seharusnya menjalankan fungsi koordinasi tersebut belum dibentuk, padahal Permendagri tersebut sudah disahkan 3 tahun lalu. Disamping itu, walaupun urusan sudah dibagi secara rinci pada tiap dinas dan badan, pada kenyataanya masih terjadi tumpang tidih fungsi. Meskipun strukturnya berubah, kinerjanya sama saja. Koordinasi horizontal maupun vertikal belum bisa dikatakan efisien. 


\section{Penutup}

Interaksi diantara demokrasi, desentralisasi dan kapasitas birokrasi sangat penting sehubungan dengan masalah-masalah struktural yang dihadapi negara berkembang yang memerlukan pertimbangan jangka panjang pemerintah dan tidak bisa diselesaikan melalui janji-janji kampanye kandidat yang hanya berfokus pada penyelesaian jangka pendek. Kapasistas birokrasi yang tinggi dibutuhkan sebagai kekuatan penyangga dalam pergantian pemerintahan yang sering terjadi dalam sistem demokrasi. Dengan demikian komitmen pemerintah jangka panjang bisa dijamin. Namun dalam kapasistas birokrasi di Indonesia, masih rendah. Demokrasi akan sulit berkembang apabila kapasitas birokrasi masih rendah. Itulah sebabnya reformasi birokrasi menjadi prioritas utama saat ini

Proses desentralisasi yang demokratis seringkali melibatkan bargaining politik yang inernsif dan pembuatan koalisi diantara elit dari berbagai level pemerintahan. Dari perspektif pemerintah pusat dasar dari desentralisasi meliputi dua hal penting. Pertama, dari sisi efisiensi birokrasi, penguatan pemeritah lokal berasal dari kepercayaan bahwa kebutuhan masyarakat dapat lebih efisien dijalankan dengan membawa pemerintah lebih dekat kepada konstituen lokal; dengan pengetahuan yang mencukupi tentang kondisi dan kewenangan lokal untuk mengelola urusan-urusan lokal, pemerintah kabupaten dapat memperbaiki kualitas hidup masyarakat. Kedua, partisipasi masyarakat lebih mudah dan lebih efektif pada level yang lebih rendah daripada level yang lebih tinggi karena kewenangan diberikan lebih banyak kepada kabupaten dariapada provinsi. Oleh karena itu, desentralisasi diharapkan meningkatkan tidak saja efisiensi birokrasi tapi juga akuntabilitas pemerintah. Namun apabila kita memperhatikan desentralisasi dari pandangan pemerintah lokal, desentralisasi memiliki makna yang berlawanan. Dengan memberikan otonomi yang lebih besar, pemerintah lokal bebas untuk melakukan apa yang mereka pandang lebih sesuai dengan kondisi lokal. Media massa banyak melaporkan kasus-kasus korupsi, intimidasi, dan politik uang pada pemerintah lokal, yang menobatkan kepala daerah sebagai tokoh yang sangat kuat secara politik (raja kecil). Nampaknya muncul pemikiran diantara para kepala daerah, "Mengapa kita harus mengubah aturan main yang memberikan kenyamanan bagi status quo?" Dua pandangan inilah yang harus dipertimbangkan peneliti yang berminat mengkaji bagaimana desentralisasi dijalankan di Indonesia saat ini lebih jauh lagi.

Penelitian ini menemukan bahwa reformasi birokrasi yang dilakukan di provinsi Jawa Tengah ditujukan untuk meningkatkan pelayanan publik, memperbaiki pola rekrutmen, memperbarui teknologi informasi dan memanfaatkan prinsip-prinsip manajerial sektor privat dalam pelaksanaan pengelolaan organisasi pemerintah, provinsi Jawa Tengah telah berhasil meningkatkan kapasistas birokrasi dalam menyediakan pelayanan publik, pada gilirannya ini meningkatkan legitimasi pemerintah. Namun pengembangan karir birokrat 
sangat tergantung pada hubungan personal daripada institutional. Penguasaan birokrasi merupakan salah satu srategi untuk bertahan dari politisi yang menduduki jabatan politis tertinggi. Di samping itu, upaya peningkatan efisiensi pelayanan publik pada saat yang sama dikuatkan dengan upaya resentralisasi birokrasi yang membatasi onomi birokrasi. UU Pemerintahan Daerah yang baru, UU No.23/2014 menegaskan proses resentralisasi tersebut. Dengan demikian keberhasilan reformasi birokrasi memang mampu meningkatkan efisiensi namun pada saat yang sama mengurangi otonomi birokrasi. Jargon netralitas birokrasi akan tinggal menjadi semboyan yang kosong dalam pemerintahan.

\section{Ucapan Terima Kasih}

Terimakasih kepada Susilo Utomo (Almarhum) yang telah memberikan kesempatan kepada penulis untuk ikut serta dalam memberikan masukan dalam penataan organisasi Provinsi Jawa Tengah dan membantu proses penggalian data selama penelitian dilakukan.

\section{Pendanaan}

Penulisan artikel ini dilakukan atas pembiayaan dari Dana DIPA 2017, Fakultas IImu Sosial dan Ilmu Politik, Universitas Diponegoro.

\section{Catatan}

${ }^{1}$ Istilah healing gardens adalah penggunaan area hijau di rumah sakit dan fasilitas kesehatan lainnya yang ditujukan untuk memperbaiki kesehatan pasien. Taman yang dibuat menyediakan tempat untuk berkontemplasi dan mempercepat kesembuhan bagi pasien, keluarga pasien dan staf. Setiap lingkungan hijau pada dasarnya dapat mendorong kesembuhan, namun taman memiliki kekhususan. Taman merupakan tempat yang mampu membantu terapi kesembuhan karena pada dasarnya manusia membutuhkan tempat yang menyejukan dan mententeramkan.

\section{Daftar Pustaka}

Ashford, D. E. (1993). Localism and Centralism in Europe: The Political and Legal Bases of Local Self-Government. By Edward C. Page. New York: Oxford University Press, 1992. 186p. \$52.00. American Political Science Review, 87(2), 531-532.

Aspinall, E. (2003). Local Power \& Politics in Indonesia. Flipside Digital Content Company Inc.

Blair, H. (2000). Participation and Accountability at The Periphery: Democratic Local Governance in Six Countries. World Development, 28(1), 21-39.

De Vries, M. S. (2000). The Rise and Dall of Decentralization: A Comparative Analysis of Arguments and Practices in European Countries. European Journal of Political Research, 38(2), 193-224.

Fealy, G. (2013). Indonesian Politics in 2012: Graft, Intolerance, and Hope of Change in the Late Yudhoyono Period. Southeast Asian Affairs, 103-120. Retrieved from https://www.jstor.org/stable/23471139

Foundation, A. (2002). Indonesia Rapid Decentralization Appraisal (IRDA) Second Report. 
Jakarta: Asia Foundation.

Foundation, A. (2004). Indonesia Rapid Decentralization Appraisal (IRDA) Second Report. Jakarta: Asia Foundation.

Goldsmith, M. (1995). Autonomy and City Limits. Theories of Urban Politics, 228-252.

GoRiau.com. (2017). Hasil Evaluasi Reformasi Birokrasi, Jateng dan Yogyakarta Terbaik, Riau Hanya Dapat Nilai C. C. Retrieved from https://www.goriau.com/berita/baca/hasil-evaluasi-reformasi-birokrasi-jateng-danyogyakarta-terbaik-riau-hanya-dapat-nilai-cc.html

Harsasto, P. (2015). Bisnis sebagai Kekuatan Politik: Kajian Pengembangan Strategi Kota Surakarta dalam Pengembangan Industri Pariwisata (2005-2012). Jurnal IImiah IImu Pemerintahan, 1(2), 5-14. Retrieved from https://ejournal2.undip.ac.id/index.php/jiip/article/view/1613

Ito, T. (2006). The Dynamics of Local Governance Reform in Decentralizing Indonesia: Participatory Planning and Village Empowerment in Bandung, West Java. Asian and African Area Studies, 5(2), 137-183.

Jatengprov.go.id. (2017). 3 Inovasi Pelayanan Publik Jateng Masuk Top 99. Retrieved from https://jatengprov.go.id/publik/3-inovasi-pelayanan-publik-jateng-masuk-top-99/

Litvack, J., Ahmad, J., \& Bird, R. (1998). Rethinking Decentralization in Developing Countries. The World Bank.

Rasyid, R. (2007). Otonomi Daerah: Latar Belakang dan Masa Depannya, dalam Syamsudin Haris ed. Desentralisasi Dan Otonomi Daerah: Desentralisasi, Demokratisasi \& Akuntabilitas Pemerintahan Daerah, 3-24.

Scharpf, F. W. (1978). Interorganizational Policy Studies: Issues, Concepts and Perspectives. In Interorganizational policy making: Limits to coordination and central control (pp. 345-370). Sage Publications.

Segal, L. (1997). The Pitfalls of Political Decentralization and Proposals for Reform: The Case of New York City Public Schools. Public Administration Review, 141-149.

Smith, G. (1976). The Local-Central Axis. London: Heinemann Educational.

Stake, R. E. (1995). The art of Case Study Research. sage.

TribunJateng.com. (2017). Selamat Reformasi Birokrasi Pemprov Jateng Dapat Nilai Terbaik. Retrieved from https://jateng.tribunnews.com/2017/07/23/selamatreformasi-birokrasi-pemprov-jateng-dapat-nilai-terbaik.

Yin, R. K. (2003). Case Study Research: Design and Methods Sage. Thousand Oaks.

\section{Tentang Penulis}

Priyatno Harsasto adalah dosen di Prodi Ilmu Pemerintahan, Fakultas Ilmu Sosial dan Ilmu Politik, Universitas Diponegoro. Penulis memiliki minat penelitian di bidang ekonomi politik, kebijakan publik dan politik lokal. 